\title{
Seasonal Incidence of Major Insect and Mite Pests of Jasmine
}

\author{
C. M. Kiran ${ }^{1}$, Jayalaxmi Narayan Hegde ${ }^{2 *}$, A. K. Chakravarthy ${ }^{3}$, \\ D. Thippesha ${ }^{2}$ and C. M. Kalleshwarswamy ${ }^{2}$
}

${ }^{1}$ Department of Agricultural Entomology, UAHS, Shivamogga

${ }^{2}$ University of Agricultural and Horticultural Sciences, Navile, Shivamogga, Karnataka, India

${ }^{3}$ Indian Institute of Horticultural Research Station, Hessaraghatta, Bangalore, Karnataka, India

*Corresponding author

\section{A B S T R A C T}

Keywords

Jasmine, insect and mite pest, Elasmopalpus jasminophagus,

Hendecasis

duplifascialis, Nausinoe geometrialis, Thrips,

Tetranychus sp.

seasonal incidence

Article Info

Accepted:

30 August 2017

Available Online:

10 October 2017
Investigation on Seasonal incidence of major insect and mite pests of jasmine was carried out at College of Agriculture, Navile, UAHS, Shivamogga during 2016-17. During the study, thirteen species of insect and mite pests were found damaging the jasmine crop. Among them, bud borers, Elasmopalpus jasminophagus (Hampson) and Hendecasis duplifascialis (Hampson), leaf web worm, Nausinoe geometrialis (Guenee) was found to feed on leaves. Red spider mite, Tetanychus sp. and thrips were found to suck the sap from jasmine leaves. Out of these insect and mite pests, banana flower thrips, Thrips florum is the first report infesting jasmine from India. Bud borer, E. jasminophagus was predominant pest with a maximum incidence of 38.85 per cent affected buds during first fortnight of January. Incidence of bud borer, E. jasminophagus was significant and negatively correlated with minimum temperature, while maximum temperature was nonsignificant and positively correlated.

\section{Introduction}

Jasmine is considered as the "Queen of fragrance" which belongs to the family Oleaceae. The genus Jasminum comprises of more than 200 species and is mostly tropical in distribution (Abdul Khader and Kumar, 1995). It is exquisitely scented to soothe and refresh, and is one of the oldest fragrant flowers cultivated by man. Jasmine flower is native to India cultivated in 12,250 ha with a production of 65,230 tonnes of loose flowers and 1,700 tonnes of cut flowers. Karnataka is the highest producer of jasmine flowers and during the year 2014 produced 43,600 MT of jasmine flower in 6,600 ha (Anon., 2014). India exports jasmine flowers to the neighbouring countries like Sri Lanka, Singapore, Malaysia and Gulf. In South India, large quantities of jasmine flowers are used by women folk for adorning their hairs. The flowers are also used for the production of perfumes and attars (Arumugam et al., 2002).

Jasmine is affected by various insects, mites, diseases, and nematodes which pose serious threat to jasmine cultivation. Among the insect pests, bud borer, Hendecasis 
duplifascialis (Hampson) (Crambidae; Lepidoptera); bud borer/ gallery worm Elasmopalpus jasminophagus (Hampson); (Pyralidae: Lepidoptera); and leaf web-worm, Nausinoe geometralis (Guenee), (Crambidae; Lepidoptera), thrips, Isoneurothrips orientalis (Bagn.) (Thysanoptera: Thripidae); and mites (Tetranychidae: Acarina) cause major damage (David, 1958).

The mean number of population of gallery worm, Elasmopalpus jasminophagus on jasmine was 21.58 larvae per 25 clusters (Roopini, 2016). The incidence of bud borer, H. dulifascilalis was maximum during second fortnight of February with 31.94 per cent bud damage (Neelima, 2005). Gunasekaran (1989) reported that the incidence of leaf web worm, $N$. geometralis was maximum during November with 12.70 per cent. Sudhir (2002) noticed that the population of Tetranychus urticae Koch. ranged from 8.19 to 16.86 per leaf on J. sambac. Neelima (2005) reported that maximum population of thrips, Isothrips orientalis noticed during second fortnight of April with an incidence of 196 thrips per twenty leaves. The present investigation was carried out to study the diffident insect and mite pests damaging the jasmine crop in Shivamogga, and their seasonal incidence.

\section{Materials and Methods}

Field study was carried out in jasmine plots of the Department of Horticulture, College of Agriculture, Navile, UAHS, Shivamogga. All recommended cultivation practices as per the package of practices were followed except plant protection measures.

To study the seasonal incidence, ten jasmine plants were selected randomly and tagged. From such tagged plants fortnightly observations were taken from February 2016 to January 2017. The methodologies followed to record the incidence of different pests of jasmine are given below (Sudhir, 2002).
Bud borer, Elasmopalpus jasminophagus (Hampson)

Total number of buds and number of buds affected were recorded in 5 randomly selected shoots. The extent of damage was expressed in per cent affected buds.

Number of buds affected

Per cent affected buds = ------------- x 100

Total number of buds

\section{Bud borer, Hendecasis duplifascialis (Hampson)}

Total number of buds and number of bored buds were recorded in 5 randomly selected shoots. The extent of damage was expressed in per cent bored buds.

Number of buds with bore holes Per cent bored buds = ------- x 100 Total number of buds

\section{Leaf web worm, Nausinoe geometrialis} (Guenee)

Total number of webbings made by the larvae were counted and expressed as number of webs per plant.

\section{Red spider mite, Tetranychus sp.}

Total number of mites present on apical three leaves of plant were counted under microscope and expressed as number of mites per leaf.

\section{Thrips}

Three flower clusters one from the bottom, one from middle and one from the top canopy were selected and beaten against white cardboard sheet and the thrips collected were counted. The incidence of thrips was expressed as number of thrips per flower cluster. 


\section{Statistical analysis}

Results obtained during the study of seasonal incidence of insect and mite pests of jasmine were correlated and regressed with various weather parameters. The weather conditions recorded at the experimental site were obtained from meteorological observatory of College of Agriculture, Navile, UAHS, Shivamogga.

\section{Results and Discussion}

During the study period, thirteen species of insect and mite pests were recorded to be infesting jasmine crop. Bud borer, Elasmopalpus jasminophagus (Hampson) and bud borer, Hendecasis duplifascialis (Hampson) both were found to feed on flower buds. Leaf web worm, Nausinoe geometrialis (Guenee) and Nausinoe perspectata (Fabricius) were found to feed on leaves by webbing the leaves. Sucking pests include red spider mite, Tetanychus sp. sucked the sap from leaves, banana flower thrips, Thrips florum Schmutz, star jasmine thrips, Thrips orientalis (Bagnall) sucked the sap from flower buds and leaves, jamine leaf thrips, Bathrips jasminae Ananthakrishnan sucked the sap from the leaves, panicle thrips, Haplothrips ganglbaueri Schmutz, sucked the sap from bud and leaves, jasmine whitefly, Kanakarajiella vulgaris (Singh) and Aleuroclava jasmini (Takahashi) were found to suck the sap from the under surface of the leaves, brown spotted stink bug, Antestiopsis cruciate (Fabricius) sucked the sap from buds and leaves, tinged bug Corythanma ayyari Drake sucked sap from leaves. Thrips species B. jasminae, T. orientalis and $H$. ganglbaueri were recorded on Jasminum sambac whereas B. jasminae and T. florum were recorded to be infesting Jasminum multiflorum. Jasmine whitefly, Kanakarajiella vulgaris (Singh) and Aleuroclava jasmini (Takahashi) were found to infest J. sambac. Among these pests, banana flower thrips, Thrips florum is the first report infesting jasmine from India (Table 1).

Among them bud borer, Elasmopalpus jasminophagus (Hampson) and bud borer, Hendecasis duplifascialis (Hampson) leaf web worm, Nausinoe geometrialis (Guenee), sucking pests include red spider mite, Tetanychus sp., and thrips, banana flower thrips, Thrips florum Schmutz, star jasmine thrips, Thrips orientalis (Bagnall), jamine leaf thrips, Bathrips jasminae Ananthakrishnan, panicle thrips, Haplothrips ganglbaueri Schmutz were found to be major pests infesting jasmine.

The mean of fortnightly observations on seasonal incidence of these five major pests of jasmine are presented in the Table 2 and graphically represented in Fig 1 . The incidence major insect and mite pests of jasmine was correlated with weather parameters like maximum temperature, minimum temperature, morning relative humidity, evening relative humidity and rainfall during February 2016 to January 2017 (Table 3).

\section{Bud borer/ Gallery worm, Elasmopalpus jasminophagus}

The prevalence of bud borer, $E$. jasminophagus was there throughout the year. Peak occurrence of this bud borer was found during the first fortnight of January (38.85\% affected buds). Minimum occurrence was found during the second fortnight of April (7.54\% affected buds) (Table 1).

Minimum temperature $(\mathrm{r}=\quad-0.461)$ was significant and negatively correlated with the occurrence of bud borer while maximum temperature $(r=0.176)$ was non-significant and positively correlated. All the other weather parameters viz, evening relative humidity $(\mathrm{r}=-0.372)$, morning relative 
humidity $(r=-0.350)$ and rainfall $(r=-0.327)$ were non-significant and negatively correlated with the bud borer incidence. The multiple linear regression equation fitted with five weather parameters to anticipate the incidence of bud borer, was $\mathrm{Y}=25.701+$ $0.804 \mathrm{MT}-1.551 \mathrm{mt}-0.132 \mathrm{RH} 1+0.162 \mathrm{RH}_{2}-$ 0.009RF + 7.229. Where, $\mathrm{MT}=\max$. temp., $\mathrm{mt}=$ min. temp., $\mathrm{RH} 1$ and $\mathrm{RH}_{2}=$ morning and evening relative humidity and $\mathrm{RF}=$ rainfall. The value of coefficient of determination $R^{2}$ revealed that that the seasonal incidence of bud borer, was influenced by weather parameters to an extent of 30.00 per cent (Table 3).

Study on the seasonal incidence of the bud borer revealed that this pest was prevalent throughout the year. This result is on par with Shobitha (2002) who reported that the incidence of bud borer was prevalent throughout the year. Sudhir (2002) reported the incidence of this pest during the study period from November to July. Roopini (2016) reported the prevalence of bud borer throughout the study period i.e., from August to March since both have studied incidence of this pests only during some part of the year.

Peak occurrence of bud borer was found during first fortnight of January. Shobitha (2002) and Roopini (2016) reported that the peak incidence of bud borer was during the second fortnight of January with incidence of 44 larvae per 30 flower clusters and 42.90 larvae per 25 flower clusters, respectively. Minimum occurrence of the above pest was found during the second fortnight of April. This finding is in line with Shobitha (2002) who revealed lowest incidence during first fortnight of May and second fortnight of April. However in contradiction Roopini (2016) opined that minimum occurrence during the first fortnight of August and second fortnight of December since the study had not been continued up to April.
Minimum temperature $(\mathrm{r}=-0.461)$ was significant and negatively correlated with the occurrence of bud borer. This result is on par with Roopini (2016) who also reported that minimum temperature had significant negative correlation with bud borer. Maximum temperature was non-significant and positively correlated. All other weather parameters like evening relative humidity, morning relative humidity and rainfall were non-significant and negatively correlated with the pest incidence. This is on par with the results of Shobitha (2002) who also reported non-significant correlation with the maximum temperature, evening relative humidity, morning relative humidity and rainfall. Regression analysis revealed that seasonal incidence of bud borer was influenced by weather parameters to an extent of 30 per cent. Hence it is concluded that minimum temperature mainly influenced the population of bud borer, Elasmopalpus jasminophagus

\section{Bud borer, Hendecasis duplifascialis}

Incidence of bud borer, $H$. duplifascialis was prevalent throughout the year. Maximum incidence of bud borer was noticed during the first fortnight of August (31.87\% bored buds). Minimum incidence was recorded during the first fortnight of February (3.39\% bored buds) (Table 2).

The incidence of bud borer was significant and positively correlated with evening relative humidity $(\mathrm{r}=0.646)$, non-significant and positively correlated with minimum temperature $(\mathrm{r}=0.325)$, morning relative humidity $(\mathrm{r}=0.394)$ and rainfall $(\mathrm{r}=0.308)$. However, non-significant negative correlation was found with maximum temperature $(\mathrm{r}=$ 0.370). The multiple linear regression equation fitted with five weather parameters to predict incidence of bud borer was $\mathrm{Y}=$ $22.130+0.570 \mathrm{MT}-0.373 \mathrm{mt}-0.073 \mathrm{RH}_{1}+$ $0.498 \mathrm{RH}_{2}-0.120 \mathrm{RF}+5.283$. 
Table.1 Insect pests and their damage recorded on jasmine during 2016-17 at Shivamogga

\begin{tabular}{|c|c|c|c|c|}
\hline $\begin{array}{l}\text { SL } \\
\text { NO. }\end{array}$ & Common name & Scientific name & $\begin{array}{c}\text { Plant parts affected/ Nature of } \\
\text { damage }\end{array}$ & Order: Family \\
\hline 1 & Bud borer & Elasmopalpus jasminophagus (Hampson) & Flower buds - borer & Lepidoptera: Pyralidae \\
\hline 2 & Bud borer & Hendecasis duplifascialis (Hampson) & Flower buds - borer & Lepidoptera: Crambidae \\
\hline 3 & Leaf web worm & Nausinoe geometrialis (Guenee) & Buds and leaves - defoliater & Lepidoptera: Crambidae \\
\hline 4 & Leaf web worm & Nausinoe perspectata (Fabricius) & Buds and leaves - defoliater & Lepidoptera: Crambidae \\
\hline 5 & Red spider mite & Tetranychus sp. & Leaves - Sucking pest & Acari: Tetranychidae \\
\hline 6 & Banana flower thrips & Thrips florum Schmutz & Buds and leaves - Sucking pest & Thysanoptera: Thripidae \\
\hline 7 & Star jasmine thrips & Thrips orientalis (Bagnall) & Buds and leaves - Sucking pest & Thysanoptera: Thripidae \\
\hline 8 & Jamine leaf thrips & Bathrips jasminae Ananthakrishnan & Leaves - Sucking pest & Thysanoptera: Thripidae \\
\hline 9 & Panicle thrips & Haplothrips ganglbaueri Schmutz & Buds and leaves - Sucking pest & Thysanoptera: Thripidae \\
\hline 10 & Jasmine whitefly & Kanakarajiella vulgaris (Singh) & Leaves - Sucking pest & Hemiptera: Aleyrodidae \\
\hline 11 & Jasmine whitefly & Aleuroclava jasmini (Takahashi) & Leaves - Sucking pest & Hemiptera: Aleyrodidae \\
\hline 12 & Brown spotted stink bug & Antestiopsis cruciate (Fabricius) & Buds and leaves - Sucking pest & Hemiptera: Pentatomidae \\
\hline 13 & Tingid bug & Corythanma ayyari Drake & Leaves and flower buds - Sucking pest & Hemiptera: Tingidae \\
\hline
\end{tabular}


Table.2 Seasonal incidence of major insect and mite pests of jasmine during 2016-17

\begin{tabular}{|c|c|c|c|c|c|}
\hline \multirow[b]{2}{*}{ Fortnight } & \multicolumn{5}{|c|}{ *Seasonal occurrence } \\
\hline & $\begin{array}{c}\text { Bud borer } \\
\text { (\% affected } \\
\text { buds) } \\
E .\end{array}$ & $\begin{array}{c}\text { Bud borer } \\
\text { (\% bored } \\
\text { buds) } \\
H .\end{array}$ & $\begin{array}{c}\text { Leaf web worm } \\
\text { (No. of webs } \\
\text { /bush) } \\
\text { N. geometralis }\end{array}$ & $\begin{array}{c}\text { Spider mite } \\
\text { (No. of mites/ } \\
\text { leaf) } \\
\text { Tetranychus }\end{array}$ & $\begin{array}{l}\text { Thrips } \\
\text { (No./ } \\
\text { flower } \\
\text { cluster) }\end{array}$ \\
\hline February -01 & 29.74 & 3.39 & 0.00 & 1.86 & 5.67 \\
\hline February -02 & 25.40 & 3.61 & 0.00 & 2.76 & 7.00 \\
\hline March-01 & 22.35 & 6.58 & 0.00 & 3.20 & 10.33 \\
\hline March-02 & 21.50 & 5.60 & 0.00 & 3.76 & 11.00 \\
\hline April-01 & 23.45 & 6.56 & 0.00 & 4.23 & 8.00 \\
\hline April-02 & 7.54 & 4.65 & 1.10 & 5.80 & 9.33 \\
\hline May-01 & 9.50 & 8.13 & 2.20 & 1.66 & 12.33 \\
\hline May-02 & 18.12 & 11.85 & 2.50 & 1.33 & 7.00 \\
\hline June-01 & 17.80 & 11.14 & 1.80 & 0.53 & 4.67 \\
\hline June-02 & 18.90 & 9.21 & 1.50 & 0.56 & 0.00 \\
\hline July-01 & 20.24 & 12.35 & 1.30 & 0.16 & 0.00 \\
\hline July-02 & 10.52 & 20.32 & 2.40 & 0.56 & 0.00 \\
\hline August-01 & 11.17 & 31.87 & 3.00 & 0.28 & 0.00 \\
\hline August-02 & 14.53 & 22.91 & 3.40 & 0.33 & 0.00 \\
\hline September-01 & 22.54 & 15.24 & 3.30 & 0.30 & 0.00 \\
\hline September-02 & 17.51 & 15.64 & 3.70 & 0.33 & 2.33 \\
\hline October-01 & 23.50 & 13.10 & 4.10 & 0.50 & 4.33 \\
\hline October-02 & 21.40 & 13.48 & 4.20 & 0.40 & 4.67 \\
\hline November-01 & 23.50 & 9.30 & 4.60 & 1.60 & 5.33 \\
\hline November-02 & 19.64 & 6.80 & 4.30 & 1.70 & 3.67 \\
\hline December-01 & 19.00 & 4.57 & 0.00 & 1.50 & 3.00 \\
\hline December-02 & 10.53 & 5.18 & 0.00 & 0.70 & 4.33 \\
\hline January-01 & 38.85 & 4.37 & 0.00 & 1.80 & 4.67 \\
\hline January-02 & 35.54 & 5.33 & 0.00 & 0.60 & 6.33 \\
\hline
\end{tabular}

* Mean of observations from 10 bushes

01- First fortnight of the month

02- Second fortnight of the month 
Table.3 Correlation and regression analysis of incidence for major insect and mite pests of jasmine with weather parameters during 2016-17

\begin{tabular}{|c|c|c|c|c|c|c|c|}
\hline \multirow[b]{2}{*}{ Insects } & \multicolumn{5}{|c|}{ Correlation coefficient } & \multirow[b]{2}{*}{$\mathbf{R}^{2}$} & \multirow[b]{2}{*}{ Regression Equation } \\
\hline & $\begin{array}{c}\text { Max. } \\
\text { Tem. } \\
\left(\mathbf{X}_{1}\right)\left({ }^{\circ} \mathrm{C}\right) \\
\end{array}$ & $\begin{array}{l}\text { Min. Tem. } \\
\left(\mathbf{X}_{2}\right)\left({ }^{\circ} \mathrm{C}\right)\end{array}$ & $\begin{array}{c}\text { RH-I } \\
\left(\mathbf{X}_{3}\right)(\%)\end{array}$ & $\begin{array}{l}\text { RH-II } \\
\left(\mathbf{X}_{4}\right)(\%)\end{array}$ & $\begin{array}{l}\mathbf{R F} \\
\left(\mathbf{X}_{5}\right) \\
(\mathbf{m m}) \\
\end{array}$ & & \\
\hline $\begin{array}{c}\text { Bud borer, } \\
\text { E. jasminophagus } \\
\end{array}$ & 0.176 & $-0.461 *$ & -0.350 & -0.372 & -0.327 & 0.300 & $\begin{array}{l}Y=25.701+0.804 X_{1}-1.551 X_{2}-0.132 X_{3}+0.162 X_{4} \\
0.009 X_{5}+7.229\end{array}$ \\
\hline $\begin{array}{c}\text { Bud borer, } \\
\text { H. duplifascialis } \\
\end{array}$ & -0.370 & 0.325 & 0.394 & $0.646^{*}$ & 0.308 & 0.556 & $\begin{array}{l}Y=-22.130+0.570 X_{1}-0.373 X_{2}-0.073 X_{3}+0.498 X_{4}- \\
0.120 X_{5}+5.283\end{array}$ \\
\hline $\begin{array}{l}\text { Leaf web worm, } \\
\text { N. geometralis } \\
\end{array}$ & -0.359 & 0.199 & 0.369 & $-0.426 *$ & 0.210 & 0.244 & $\begin{array}{l}Y=4.196-0.415 X_{1}-0.314 X_{2}+0.163 X_{3}+0.421 X_{4^{-}} \\
0.160 X_{5}+16.647\end{array}$ \\
\hline $\begin{array}{l}\text { Red spider mite, } \\
\text { Tetranychus sp. }\end{array}$ & $0.704^{*}$ & 0.183 & -0.159 & $-0.578^{*}$ & $-0.433^{*}$ & 0.750 & $\begin{array}{l}Y=-1.809-0.043 X_{1}+0.361 X_{2}+0.038 X_{3}-0.091 X_{4^{-}} \\
0.001 X_{5}+0.833\end{array}$ \\
\hline Thrips & $0.887^{*}$ & 0.128 & $-0.425^{*}$ & $-0.721 *$ & $-0.503^{*}$ & 0.906 & $\begin{array}{l}Y=-26.540+0.881 X_{1}+1.850 X_{2}+0.019 X_{3} \\
0.440 X_{4}+0.019 X_{5}+3.887\end{array}$ \\
\hline
\end{tabular}

* Significant at $5 \%$ level of probability

Note: $\mathrm{X}_{1}$ : Maximum Temperature $\left({ }^{\circ} \mathrm{C}\right)$

Rainfall (mm)

$\mathrm{X}_{2}$ : Minimum Temperature $\left({ }^{\circ} \mathrm{C}\right) \quad \mathrm{X}_{3}$ : Morning Relative humidity $(\%), \mathrm{X}_{4}$ : Evening Relative humidity $(\%)$ and $\mathrm{X}_{5}$ :

Fig.1 Seasonal incidence of major insect and mite pests of jasmine during 2016-17 at Shivamogga

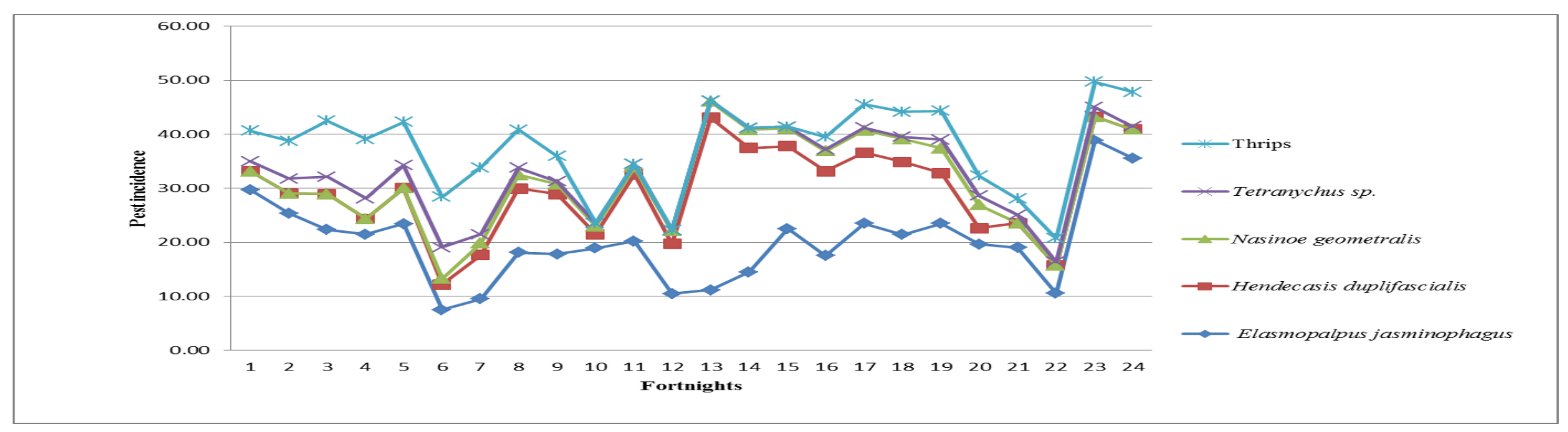


The value of $\mathrm{R}^{2}$ for this bud borer was 0.556 which implied that 55.60 per cent variation in bud borer population was due to above weather parameters (Table 3). Study on the seasonal incidence of bud borer, $H$. duplifascialis revealed that this pest was prevalent throughout the year starting from the first fortnight of February to second fortnight of January. This result is closely confirmatory with the findings of Amutha (1994) and Shobitha (2002) who reported the infestation of bud borer throughout the year.

The per cent bored buds was lowest during the first fortnight February with 3.39 per cent bored buds and increased gradually and reached peak during August with a mean of 27.35 per cent bored buds. Peak population during August, might be due to more availability of buds. The present results are comparable with the findings of Gunasekaran (1989) who reported that bud borer incidence was more during monsoon period and also reports of Amutha (1994) and Vanitha (2001) who reported that the maximum infestation $(21.5 \%)$ was recorded during September. It is also on par with results of Sudhir (2002) who reported that bud borer incidence was more during May (23.15 per cent) and July (18.32 per cent). The incidence of bud borer $H$. duplifascialis was significant and positively correlated with evening relative humidity $(\mathrm{r}=$ 0.646), non-significant and negatively correlated with the maximum temperature. Whereas, the incidence was non-significant positively correlated with minimum temperature, morning relative humidity and rainfall. These results are in line with Gunasekaran (1989) and Shobitha (2002) who reported that there was no significant correlation between weather parameters and the extent of bud borer damage. However, evening relative humidity was significant and positively correlated. This difference might be due to the variation in the weather conditions. Regression analysis revealed that 55.60 per cent variation in bud borer population was due to weather parameters. It is concluded that evening relative humidity mainly influenced the incidence of bud borer. Hendecasis duplifascialis

\section{Leaf web worm, Nausinoe geometrialis}

The incidence of leaf web worm, $N$. geometralis was nil during January, February, March, first fortnight of April and December months. The peak incidence of leaf web worm was during the first fortnight of November (4.60 webs/ bush) (Table 2).

The occurrence of leaf web worm was significant and negatively correlated with evening relative humidity $(\mathrm{r}=-0.426)$, nonsignificant and positive correlation was found with the minimum temperature $(r=0.199)$, morning relative humidity $(\mathrm{r}=0.369)$, rainfall $(\mathrm{r}=0.210)$. Leaf web worm population showed non-significant and negative correlation with maximum temperature $(\mathrm{r}=$ 0.359) (Table 3). The multiple linear regression equation fitted with weather parameters to anticipate the incidence of leaf web worm was $\mathrm{Y}=4.196-0.415 \mathrm{MT}$ $0.314 \mathrm{mt}+0.163 \mathrm{RH}_{1}+0.421 \mathrm{RH}_{2}-0.160 \mathrm{RF}+$ 16.647. The value of coefficient of determination $\mathrm{R}^{2}$ for leaf web worm was 0.244 which implied that 24.40 per cent variation in leaf web worm population was due to above mentioned weather parameters (Table 3).

\section{Leaf web worm, Nausinoe geometralis}

Study on the seasonal incidence of leaf web worm revealed that this pest prevailed during the second fortnight of April to second fortnight of November. The maximum incidence of leaf webworm was found during the cooler months i.e., during November (4.45 webs/ plant) and October months (4.15 webs/plant). These results are in line with Shukla and Sandhu (1988) who stated that June and October are peak periods for leaf 
webworm activity, Gunasekaran (1989) who noticed the higher incidence of leaf web worm during November. The incidence of the pest was maximum during September (3.69 webs/plant) and November (2.76 webs/plant) months according to Sudhir (2002). Neelima (2005) reported that peak population of web worm occured during September and October with an incidence of 24.5 webs per 20 twigs and 26 webs per 20 twigs respectively.

The occurrence of leaf web worm, $N$. geometralis was significant and positively correlated with evening relative humidity $(\mathrm{r}=$ -0.426), non-significant and positive correlation were found with the minimum temperature, morning relative humidity and rainfall. Meanwhile leaf web worm population showed non-significant and negative correlation with maximum temperature. Sudhir (2002) also observed non-significant negative correlation of leaf web worm population with maximum temperature. Similarly, Positive correlation of minimum temperature, relative humidity and rainfall with leaf web worm population was reported by Neelima (2005). Regression analysis revealed that 24.40 per cent variation in bud borer population was due to weather parameters. It is concluded that evening relative humidity mainly influenced the incidence of leaf web worm.

\section{Red spider mite, Tetranychus sp.}

Incidence of red spider mite, Tetranychus sp. was prevalent throughout the year. The population attained its peak during the second fortnight of April (5.80 mites/ leaf), whereas least incidence was recorded during the first fortnight of September (0.3 mites/ leaf) (Table $2)$. The incidence of red spider mite was positive and significantly correlated with maximum temperature $(\mathrm{r}=0.704)$ while evening relative humidity $(\mathrm{r}=-0.578)$ and rainfall $(\mathrm{r}=-0.433)$ were significant and negatively correlated. Whereas nonsignificant positive correlation was found with minimum temperature $(\mathrm{r}=0.183)$. However morning relative humidity $(\mathrm{r}=$ 0.159) was non-significant and negatively correlated (Table 3).

Due to the influence of weather parameters on red spider mite the regression equation obtained was $\mathrm{Y}=$-1.809$0.043 \mathrm{MT}+0.361 \mathrm{mt}+0.038 \mathrm{RH}_{1}-0.091 \mathrm{RH}_{2}$ $0.001 \mathrm{RF}+0.833$. The $\mathrm{R}^{2}$ value for red spider mite was 0.750 which implied that 75.00 per cent variation in red spider mite population was due to above mentioned weather parameters (Table 3).

\section{Red spider mite, Tetranychus sp.}

Study on the seasonal incidence of red spider mite, Tetranychus sp. revealed that this pest was prevalent throughout the study period with a peak population during the second fortnight of April with 5.8 mites per leaf, may be due to high temperature and lesser rain fall which gradually decreased due to showers during subsequent periods. These results are in conformity with David (1958) and Rajkumar et al., (2005) who reported the incidence of red spider mite throughout the year on jasmine. The lowest population $(0.16$ mites/ leaf) was recorded during first fortnight of July which may be due to heavy rainfall received during that period. These results are confirmatory with Rajkumar et al., (2005) who reported that maximum population during second fortnight of April and first fortnight of May due to dry spells and absence of rainfall. The population fluctuation of red spider mite was significant and positively correlated with maximum temperature which is in close conformity with the report of Sarkar and Somochowdhary (1989) who reported that increase in population of red spider mite which commenced from January with increase in atmospheric temperature which declined significantly with the receipt of heavy shower. Sudhir (2002) noticed the significant and 
positive correlation of spider mite population with maximum temperature and an increase in one degree Celsius increased the mite population by 0.28 per cent. Rajkumar et al., (2005) observed significant and positive correlation of mites with maximum temperature which influenced population to the tune of 60.30 per cent.

Mite population showed non-significant positive correlation with minimum temperature, whereas morning relative humidity was non-significant negatively correlated.

Evening relative humidity $(\mathrm{r}=-0.578)$ and rainfall $(\mathrm{r}=-0.433)$ were significant and negatively correlated. These findings are in close conformity with the findings of Sudhir (2002) who reported negative correlation of rainfall and morning relative humidity with mite population which influenced the population to the tune of 40.10 , and Neelima (2005) who reported non-significant negative correlation with relative humidity, Rajkumar et al., (2005) who reported the positive and non-significant relationship with mite population and minimum temperature. Regression analysis revealed that 75.00 per cent variation in red spider mite population was due to above mentioned weather parameters. Hence, it is concluded that evening relative humidity and rainfall mainly influence the incidence of red spider mite.

\section{Thrips}

Population of thrips was at its peak during the first fortnight of May (12.33 thrips/ flower cluster). Whereas nil incidence was recorded during the second fortnight of June, June, July, August and September first fortnight of the year (Table 2). The incidence of thrips had positive and significant correlation with maximum temperature $(\mathrm{r}=0.887)$ whereas, population was significant and negatively correlated with morning relative humidity $(\mathrm{r}=$
$-0.425)$, evening relative humidity $(\mathrm{r}=-0.721)$ and rainfall $(\mathrm{r}=-0.503)$ meanwhile, minimum temperature $(\mathrm{r}=0.128)$ had positive and nonsignificant correlation (Table 3 ).

The multiple linear regression equation fitted with independent weather parameters to predict incidence of thrips population was $\mathrm{Y}=-26.540+0.881 \mathrm{MT}+1.850 \mathrm{mt}+0.019 \mathrm{RH}_{1}-$ $0.440 \mathrm{RH}_{2}+0.019 \mathrm{RF}+3.887$. The value of coefficient of determination $\mathrm{R}^{2}$ for thrips was 0.906 which revealed that 90.60 percent variation in thrips population was governed by above said weather parameters (Table 3 ).

\section{Thrips}

Study on the seasonal incidence of thrips revealed that this pest was noticed throughout the study period except second fortnight of June, July, August and first fortnight of September. The nil incidence during the above period might be due to low temperatures and high rainfall. This is on par with results obtained by Neelima (2005) who reported the nil incidence of thrips during July, August and October months. The peak incidence was noticed during the first fortnight of May with 12.33 thrips per flower cluster might be due to higher temperature. This is in close confirmatory with results of Neelima (2005) who reported that maximum population of thrips noticed during second fortnight of April. The seasonal incidence of thrips was significant positively correlated with maximum temperature and morning relative humidity. Significant negative correlation was found with evening relative humidity. Minimum temperature was nonsignificant and positively correlated with thrips incidence. This result is in line with the findings of Neelima (2005) who reported positive correlation with maximum temperature and negative correlation with relative humidity and rainfall. Roopini (2016) also reported that maximum temperature was significant and positively related with jasmine 
thrips incidence while evening relative humidity was significant negatively related. Regression analysis revealed that 90. 60 per cent variation in red spider mite population was due to above mentioned weather parameters.

It is concluded that maximum temperature, morning relative humidity and evening relative humidity mainly influenced the incidence of thrips.

\section{References}

Abdul Khader, J. B. and Kumar, N. 1995. Genetic resources of jasmine. In: Advances in Horticulture, Ornamental plants Eds. Chadha, K. L. and Bhattacharjee, S. K., Malhotra Publishing House (India), New Delhi, pp. 121132.

Amutha, S. 1994. Bio-ecology and control of three pyralids, Hendecasis duplifascialis (Hampson), Nausinoe geometralis (Guenee) and Margaronia unionalis (Hubner). on Jasminum sp. Ph.D. Thesis, University of Madras., Madras.

Anonymous, 2014. Annual Report (2014-15). Indian Horticultural database. NHB Ministry of Agriculture, Government. of India, P. 286.

Arumugam, T., Jawaharlal, M., Vijaykumar, M. and Bhattacharjee, S. K. 2002. Jasmine Technical Bulletin No. 17, Ind. Agric. Res. Inst., New Delhi (India).

David, S. K. 1958. Insects and mites affecting jasmine in Madras state. Madras Agricultural Journal, 45: 146-150.

Gunasekaran, V. 1989. Studies on the bio-ecology of jasmine pest complex. M. Sc. Thesis, Tamil Nadu Agricultural University, Coimbatore.

Neelima, Y. 2005. Bio-ecology and management of jasmine pests, M. Sc. (Agri.) Thesis, Acharya N. G. Ranga Agriccultural University Rajendra nagar, Hyderabad.

Rajakumar, E., Hugar, P. S. and Kattimani, K. N. (2005) Seasonal incidence of red spider mite, Tetranychus urticae Koch. (Acari: Tetranychidae) on jasmine. Karnataka Journal of Agricultural Sciences, 18: 150-153.

Roopini, G. A. (2016) Studies on seasonal incidence of pests on Jasminum spp. emphasizing on bud borer complex and their management strategies on J. multiflorum $\mathrm{M}$. Sc. Thesis, University Horticultural Sciences, Bagalkot.

Sarkar, P. K. and Somochowdhary, A. K. (1989) Observations on natural enemies found in association with coconut mite. Raoiella indica Hirst. Bulletin of Entomological Research, 28: 104-107.

Shobitha, C. A. (2002) Studies on the bud borer complex of jasmine. M. Sc. Thesis, University Agricultural Sciences Bengaluru.

Shukla, G. K. AND Sandhu, G. S. (1988) New record of natural enemies of Jasminum leaf web worm in India. Bulletin of Entomology, 24: $135-136$.

Sudhir, B. (2002) Survey and management of insect and mite pests of Jasminum spp. M. Sc. Thesis, University Agricultural Sciences, Dharwad.

Suganthi, A., Chandrasekaran, S. and Regupathy, A. (2006) Bio-efficacy of lambda-cyhalothrin against bud worm, Hendecasis duplifascialis (Hampson) on jasmine, Pesticide Research Journal, 18: 138-140.

Vanitha, 2001. Management of major pests of jasmine (Jasminum spp.) with special reference to botanicals and biological control. M. Sc. Thesis, Tamil Nadu Agricultural University Coimbatore.

\section{How to cite this article:}

Kiran C. M., Jayalaxmi Narayan Hegde, A. K. Chakravarthy, D. Thippesha and Kalleshwarswamy C. M. 2017. Seasonal Incidence of Major Insect and Mite Pests of Jasmine. Int.J.Curr.Microbiol.App.Sci. 6(10): 5060-5070. doi: https://doi.org/10.20546/ijcmas.2017.610.480 